\title{
The contribution of self determination and peer conformity to sexual harassment
}

\section{Weni Puspita Sari ${ }^{1}{ }$ Firman $^{1}$}

${ }^{1}$ Universitas Negeri Padang

*Corresponding author, e-mail: weni.p92@yahoo.com

\begin{abstract}
This research is motivated by the rise of cases of sexual harassment that occur among teenagers. Sexual harassment by teenagers occurs in verbal, visual, and physical forms such as: sexual jokes, flirting and touching someone's sensitive area. Factors that influence adolescents to commit sexual harassment are due to peer group involvement and the inability of adolescents to make choices in actions that are reflected in peer conformity and self-determination. The aims of this study is to examine the contribution of self-determination to sexual harassment, to examine the contribution of peer conformity to sexual harassment, and to examine the contribution of self-determination and peer conformity together with sexual harassment. This research uses quantitative method with simple and multiple regression analysis. The study population is all students high school city of Padang who are active in 2020/2021. The number of samples in this study were 273 teenagers who were selected by cluster random sampling technique using the Slovin formula. Methods of data collection using self-determination scale, peer conformity scale, and sexual harassment scale with a Likert Scale model to then be tested for validity and reliability. The research findings show that: (1) there is a significant negative contribution between self-determination with sexual harassment shown by correlation coefficient of $R=0.736$ and $R$ Square of 0.542 , which means that the contribution of self-determination to sexual harassment is $54.2 \%$. (2) there is a significant positive contribution between peer conformity to sexual harassment shown by correlation coefficient of $R=0.767$ and $R$ Square of 0.588 , which means that the contribution of peer conformity to sexual harassment is $58.8 \%$. (3) there is a significant contribution between self-determination and peer conformity together to sexual harassment shown by correlation coefficient of $R=0.810$ and $\mathrm{R}$ Square of 0.665 , which means that the contribution of peer conformity to sexual harassment is $68.5 \%$.
\end{abstract}

Keywords: sexual harassment, self determination, peer conformity 
How to Cite: Sari, W.P., Firman, F. (2021). The contribution of self determination and peer conformity to sexual harassment. International Journal of Applied Counseling and Social Sciences, 2(2): pp. 161-167, https://doi.org/10.24036/005440ijaccs

This is an open access article distributed under the Creative Commons 4.0 Attribution License, which permits unrestricted use, distribution, and reproduction in any medium, provided the original work is properly cited. $\odot 2021$ by Author

\section{Introduction}

Nowadays cases of sexual violence often become the main news among Indonesian youth. One of the most common types of sexual violence cases is sexual harassment, where a survey conducted by Sintas Lentera Indonesia, Wadah Petisi Dering Change-org and Media Perempuan in June 2016 managed to record 25,213 respondents in all regions in Indonesia showing data on cases of sexual harassment to be the most common type of sexual violence. as many as $58 \%$ had experienced verbal sexual harassment, $25 \%$ experienced physical abuse and 6\% experienced rape (Enro Priherditityo, 2016). The Population Service, Women's Empowerment and Child Protection (DKP3A) also explained the description of the number of sexual harassment that occurred from 20162018. In 2016 there were 203 cases of sexual harassment, in 2017 there were 361 cases, and in 2018 there were 244 cases (Rahmadani \& Tianingrum, 2019).

Cases of sexual harassment have also increased in the city of Padang, the Women and Children Protection Unit (PPA) of the Padang Police noted that during JanuaryFebruary 2018 there were 13 cases of sexual harassment reported, of which 7cases occurred in January and 6 cases occurred in February (Padangkita, 2018). The number of sexual harassment in Padang City in 2018 increased more than the previous year. Then the case of sexual harassment that went viral in 2020 and became a conversation on social media, namely the case of breast robbery that occurred in the city of Padang, West Sumatera in August, where an online motorcycle taxi driver committed breast robbery on an 18 year old teenager who works as a babysitter by hugging and touching the breast of the girl (Liputan6.com, 2020, August 14).

Sexual harassment is all forms of behavior that connotes or leads to sexual things that are carried out unilaterally and are not expected by the person being targeted, causing negative reactions such as shame, anger, hatred, offence and so on in the individual who is the victim of the harassment. (BkkbN, 2012). There are various forms of sexual abuse, such as persuading or coercing a child to take part in sexual activities, encouraging a child to behave sexually inappropriately, sexual acts or non-contact sexual intercourse or interaction with a child, touching the genitals, buttocks, or breasts with or without clothing, adult filmmaking, prostitution, and so on (Brown, et al, 2015).

Sexual harassment is closely related to adolescents, the International Business Times (IBT) states that 1 in 20 teenagers (4.8\%) have experienced sexual harassment, and the perpetrators of sexual harassment are people they know such as their peers 
(Rahmadani \& Tianingrum, 2019). Furthermore, data collected by KPAI shows that from 2011 to 2016 as many as 1965 or around 30\% of teenagers in Indonesia were involved in being perpetrators of sexual harassment (Sofian, 2017). Furthermore, data from Komnas Perempuan in 2020 recorded that perpetrators of sexual harassment in the community under the age of 5 years were 10 cases, aged 6-12 years were 86 cases, and aged 13-18 years were 307 cases (kompas, 2020).

Perpetrators of sexual harassment among teenagers were also found in West Sumatra Province. 11 out of 19 or more than $50 \%$ of teenagers who live in LPKA in the Tanjung Pati area ofWest Sumatra are detained for sexual crimes. Cases of sexual harassment are also often not revealed because victims feel ashamed to report the harassment they receive and there is also no definite law for victims of sexual harassment in the light category, therefore research is one way to find out teenagers as perpetrators of sexual harassment. Research conducted (Firman \& Syahniar, 2015) at a high school in the city of Padang showed that out of 252 teenagers, around $27.37 \%$ of teenagers had been perpetrators of sexual harassment.

Sometimes they don't realize the acts of sexual harassment committed by high school teenagers, such as jokes that use sexual words, seductive glances and so on. The case occurred in a school in North Sulawesi (Sulut), where five students sexually harassed one of their female classmates. They took part and their respective duties in the sexual harassment that was carried out, where two female students groped the victim's breasts, two male students held the victim's legs and hands and another male student took a video of the immoral act that was carried out. they do it (Angela Rawis, 2020). Some of them argued that they did this just for fun and because they were just following their friends.

Adolescents with all the characteristics and developmental tasks have the potential to commit acts of sexual harassment. Adolescence is a developmental transition period between childhood and adulthood that begins at the age of 12 or 13 years and ends at the age of 20 years and is characterized by biological and psychological changes (Saputro, 2018). One of the characteristics of adolescent development is characterized by peer relationships, where interest in peers is characterized by acceptance and rejection. Teenagers spend a lot of time with their peers, so they try various roles and identify themselves with peers in order to take their place in a group. Adolescent behavior standards are formed by groups, so peer acceptance is very important for adolescents (A. Wulandari, 2014).

Adolescents who fail to fulfill their developmental tasks will easily fall into deviant behaviors caused by inappropriate peer conformity, one of which is sexual harassment behavior. Research conducted (Apsari \& Purnamasari,2018) shows that there is a positive relationship between conformity and premarital sexual behavior, which means that the higher the conformity, the higher the premarital sexual behavior, and vice versa, the lower the conformity, the lower the premarital sexual behavior. If the 
sexual behavior is not desired by the victim, it can be classified as an act of sexual harassment.

Adolescents who easily go along with their peers in committing acts of sexual harassment cannot determine which behavior is good for themselves or in other words, adolescents cannot make the right decisions in their lives. Adolescents who are unable to make decisions in making good or bad choices for himself it can be said to be problematic with his developmental task. This is related to adolescent selfdetermination. Self-determination is a person's control over what he does that comes from himself to make decisions and act according to what he wants (Haqiqi, 2016) . Further two psychologists Deci and Ryan formulate three basic aspects of psychological framing self-determination, namely,autonomy, competence, andrelatedness(Oktavianda, Husen, \& Nurbaity, 2019).

Wulandari, et al (2020) teenagers who have low self-determination will easily take deviant actions or behaviors. It can be understood that adolescents who have high selfdetermination will be able to control themselves from deviant behavior and adolescents with low self-determination will be prone to engage in deviant behavior, one of the deviant behaviors that often occurs in adolescents is that they are involved in being perpetrators of sexual harassment.

Sexual harassment that occurs in schools, especially high school environments, has recently become news on social media. The case occurred in one of the Bolang Mongondow Vocational Schools, North Sulawesi (Sulut), where five vocational students sexually harassed one of their female classmates. They took part and their respective duties in the sexual harassment that was carried out, where two female students groped the victim's breasts, two male students held the victim's legs and hands and another male student took a video of the immoral act that was carried out. they do it (Angela Rawis, 2020). Sexual harassment that occurs in high school really needs the attention of guidance and counseling teachers. BK teachers are required to be able to help students independently to develop effective daily life (KES) and be able to reduce (KES-T). If not granted precautionary measures ( preventive ) by educators, especially teachers BK in depth (intense) to youth, then in the future with advances offered, will the cases of sexual abuse committed by juveniles can be reduced or growing of time time. Starting from the above phenomenon, it is interesting to study further how the contribution of self-determinationand peer conformity to sexual harassment among high school teenagers.

\section{Method}

This study uses quantitative methods. This type of research is quantitative research with a correlational approach. The population of this study were 23,956 high school students in Padang City and a sample of 273 students were selected using cluster random sampling technique. The research instrument used a non-test instrument in the form of a Likert scale model questionnaire which was assessed by 3 validators. The 
number of each research instrument that will be distributed to students is 28 selfdetermination statements, 33 peer conformity statements, and 35 statements of sexual harassment. before being distributed to students, the instrument has passed the validity and reliability test. Validity test is done by comparing the significance of 0.05 , if $\mathrm{r}$ with a significance less than 0.05 then the item statement of the instrument is declared valid. From the results of data processing, Cronbach's Alpha value for the self-determination variable was 0.912 , the peer conformity variable was 0.931 , and the sexual harassment variable was 0.948 so that this research instrument was declared reliable. To find out how big the contribution of each variable $\mathrm{X} 1$ and $\mathrm{X} 2$ to variable $\mathrm{Y}$, the collected data were analyzed by simple and multiple regression assisted by using SPSS version 20 program.

\section{Results and Discussion}

\section{Normality test}

The results of the calculation of the normality test explain that Asimp.Sig selfdetermination is 0.294 , peer conformity is 0.275 , and sexual harassment is 0.084 . The three variables have an Asymp score. Sig. greater than the predetermined significance (0.05), it can be concluded that the data is in a normal curve distribution. This shows that one of the requirements for regression analysis has been met.

\section{Linearity Test}

The linearity test in this study is seen from the deviation from linearity of the $\mathrm{F}$ test. If the value of sig . linearity 0.05 , then the data is declared linear. The results of the linearity test show that the variable $X_{1}$ with $F_{\text {count }}(331.429)>F_{\text {table }}$ (3.89) and $X_{2}$ with $F_{\text {count }}(384225)>F_{\text {table }}$ (3.89) with $\mathrm{Y}$ known the value of sig. 0.0000 .05 ( $\mathrm{F}$ table attached), it can be concluded that the regression line between $X$ and $Y$ forms a linear line.

\section{Multicollinearity Test}

The calculation results of the multicollinearity test explain that the VIF selfdetermination value is 2.127 with a tolerance of 0.470 and the VIF value of peer conformity is 2.127 with a tolerance of 0.470 . Thus, the two VIFs are less than 10 and the tolerance value is greater than 0.1 , so it can be concluded that there is no correlation between self-determination and peer conformity.

\section{Hypothesis test}

\section{Contributions self determination with sexual harassment}

Table 1. Significance Test Results Self Determination (X1) with Sexual Harassment (Y)

\begin{tabular}{cccc}
\hline Model & $\mathbf{R}$ & $\boldsymbol{R}$ Square & Sig. \\
\hline $\mathbf{X}_{1}-\mathbf{Y}$ & 0.736 & 0.542 & 0.000 \\
\hline
\end{tabular}


Table 1 indicates that the value of $\mathrm{R}$ indicates regression coefficient self determination against sexual harassment, while the value of R Square (R2) explain the magnitude of the contribution of self-determination with sexual harassment. The results obtained in this study, the $R$ value of 0736 and the value of $R$ Square (R2) of 0.542. This means that self-determination towards sexual harassment is $54.2 \%$. Sexual harassment is a deviant act, a person with low self-determination is more prone to deviant behavior (Wulandari, et al, 2020). it can be interpreted that the higher the selfdetermination of students, the lower the student's sexual harassment behavior and vice versa.

\section{Contribution of peer conformity to sexual harassment}

Table 2. Significance Test Results of Peer Conformity (X2) with Sexual Harassment (Y)

\begin{tabular}{cccc}
\hline Model & $\mathbf{R}$ & $\boldsymbol{R}$ Square & Sig. \\
\hline $\mathbf{X}_{2}-\mathbf{Y}$ & 0.767 & 0.588 & 0.000 \\
\hline
\end{tabular}

Tabel2 explained that the value of the regression coefficient $\mathrm{R}$ indicates conformity to peer sexual harassment, while the value of R Square (R2) describes the amount of donations perceptions of students about peer conformity to sexual abuse. The results obtained in this study, the R value of 0.767 and the value of R Square (R2) of 0588 . That is, the contribution of peer conformity to harassment is $58.8 \%$. Peers can have a bad influence on students, one of the effects is free sex behavior or deviant sexual behavior (Sarwono, 2003). The results of this study are in line with research (Apsari \& Purnamasari, 2018) which shows a significant positive relationship between peer conformity and premarital sexual behavior.

\section{Contributions self Determinaton and Conformity Peers together with sexual harassment}

Table 3. Significance Test Results Self Determination (X1) with Sexual Harassment (Y)

\begin{tabular}{cccc}
\hline Model & $\mathbf{R}$ & $\boldsymbol{R}$ Square & Sig. \\
\hline $\mathbf{X}_{1} \mathbf{X}_{2}-\mathbf{Y}$ & 0.810 & 0.665 & 0.000 \\
\hline
\end{tabular}

The above table shows that the value of $\mathrm{R}$ explained the multiple regression coefficient between self determination and conformity to peer sexual harassment, whereas, the value of $\mathrm{R}$ Square (R2) describes the amount of donations together between self determination and peers against sexual harassment. The results obtained in this study, the $R$ value of 0.810 and the value of $R$ Square (R2) of 0665 . This means that the total contribution of self-determination and peer conformity to achievement motivation is $66.5 \%$.

Based on the analysis of the table above, we can understand that self-determination and peer conformity can be predicted as factors that influence sexual harassment 
behavior in high school students. This is evidenced by the large contribution of each dependent variable to the independent variable. Based on the three hypotheses in this study, it proves that there is a joint contribution between self-determination towards sexual harassment, conformity to sexual harassment, self-determination and peer conformity to sexual harassment. Self-determination and peer conformity can influence deviant behavior in a person, this is in accordance with the results of a previous study (Knee \& Neighbors, 2002) which found that there was a relationship between self-determination and peers towards excessive alcohol drinking behavior in students. The difference with this study is that the variable of deviant behavior studied in this study is sexual harassment.

\section{Conclusion}

Based on the findings and discussion of the research results, the following conclusions can be drawn: (1) There is a significant negative relationship between self-determination and adolescent sexual harassment.Thatis,the higher the self-determination of adolescents, the lower the sexual harassment behavior in the school environment. (2) There is a significant positive relationship between peer conformity and sexual harassment. That is, the higher the conformity of peers who are not good, the behavior of adolescent sexual harassment will also be high, and vice versa. (3) There is a significant relationship between self-determination and peer conformity together with high school adolescent sexual harassment. This means that the level of sexual harassment behavior is not only related to one variable, but is also related to self-determination and peer conformity. In other words, the use of self-determination and peer conformity that is not good will be able to have an influence on sexual harassment behavior of high school teenagers.

\section{References}

Angela Rawis. (2020). Kasus Siswi SMK Digerayangi di Kelas, Pemprov Sulut: Itu Bukan Bercanda. DetikNews,.

Apsari, A. R., \& Purnamasari, S. E. (2018). Hubungan Antara Konformitas Dengan Perilaku Seksual Pranikah Pada Remaja. Insight: Jurnal Ilmiah Psikologi, 19(1), 1. https://doi.org/10.26486/psikologi.v19i1.596

Brown, J., Burnette, M. L., \& Cerulli, C. (2015). Correlations Between Sexual Abuse Histories, Perceived Danger, and PTSD Among Intimate Partner Violence Victims. Journal of Interpersonal Violence, 30(15), 2709-2725. https://doi.org/10.1177/0886260514553629

Endro Priherditityo. (2016, Juli 22). Pelecehan Seksual Verbal Dianggap Lumrah di Indonesia. CCN.

Firman, Firman, S. (2015). Pencegahan Pelecehan Seksual Remaja Melalui Layanan Informasi Menggunakan Pendekatan Contextual Teaching and Learning Di Sekolah Menengah Atas (SMA).

Knee, C. R., \& Neighbors, C. (2002). Self-Determination, Perception of peer Pressure, and Drinking Among College Students. 3(32), 522-543.

Liputan6.com. (2020, Agustus 14). Polisi Kantongi Identitas Pelaku Pelecehan Seksual yang Viral di Padang. Liputan6.com/ ist.

Nasional, B. K. K. B. (2012). Buku Suplemen Bimbingan Teknis Kesehatan Reproduksi Pelecehan Seksual. UNESCO: Jakarta. 
Nita, W. (2015). Hubungan Kebiasaan Penggunaan Media Sosial Facebook Dengan Perilaku Seksual Remaja DI SMK Kanisius Unggaran.

Oktavianda, M., Husen, M., \& Nurbaity, N. (2019). Hubungan Determinasi Diri Dengan Sosial Support Di Dayah Modern Darul 'Ulum Kota Banda Aceh. JIMBK: Jurnal Ilmiah Mahasiswa Bimbingan \& Konseling, 4(4).

Padangkita. (2018, Maret 5). 13 Anak di Padang Jadi Korban Pelecehan Seksual dalam Dua Bulan Terakhir. Padangkita Multimedia Pers.

Rahmadani, I. R., \& Tianingrum, N. A. (2019). Pengaruh Teman Sebaya Terhadap Pelecehan Seksual Pada Siswa Sekolah Di Wilayah Kerja Puskesmas Harapan Baru. 152-158.

Saputro, K. Z. (2018). Memahami Ciri dan Tugas Perkembangan Masa Remaja. Aplikasia: Jurnal Aplikasi Ilmu-ilmu Agama, 17(1), 25. https://doi.org/10.14421/aplikasia.v17i1.1362

Wulandari, A. (2014). Karakteristik Pertumbuhan Perkembangan Remaja dan Implikasinya Terhadap Masalah Kesehatan dan Keperawatannya. Jurnal Keperawatan Anak, 2, 39-43. Diambil dari https://jurnal.unimus.ac.id/index.php/JKA/article/view/3954

Wulandari, A. P. (2020). Pengembangan Panduan Bimbingan Kelompok Dalam Peningkatan Determinasi Diri ( Self Determination ). 4(April), 175-184. 